\title{
Karakteristik Ekstrak Asbuton dengan Metode Asbuton Emulsi Menggunakan Peremaja Oli Bekas dan Karakteristik Penambahan Ekstrak Asbuton Emulsi pada Aspal Penetrasi 60/70 Sebagai Modifikasi Bitumen (Semarbut Aspal Tipe III)
}

\author{
Djoko Sarwono ${ }^{1)}$ F.Pungky ${ }^{2)}$ Devi Prapita Nuari ${ }^{3)}$ \\ 123) Roadmate Research Group Universitas Sebelas Maret \\ Roadmate Research Group Laboratorium Jalan Raya \\ Program Studi Teknik Sipil, Universitas Sebelas Maret, Jl. Ir. Sutami 36 A Surakarta \\ Email: 1)sarwono60@yahoo.co.id ,2)pungkypramesti@gmail.com : 3)deviprapitanuari@gmail.com,
}

\begin{abstract}
Asbuton cannot be utilized optimally in Indonesia because its terms is limited in granules form. The purpose of this research is to analyze the relations of time mixing of emulsion bitumen content in solid phase to emulsion asphalt content, characteristics of emulsion asbuton extracted, Semarbut Asphalt type III characteristic and addition of an optimum emulsion asbuton extracted that fulfill asbuton modified asphalt requirement.

Asbuton emulsions are composed of solid material (5/20 grain asbuton and used lubricant oil mixed with time variation is 3,5, 7,9 and 11 minutes with 24 hours curing time) and liquid material (texapon, HCl and aquades). The emulsion of asbuton extracted tested the bitumen content until the optimum bitumen content was obtained and then mixed it into penetration asphalt 60/70 with variation of content is 30\%, 35\%, 40\%, 45\%, and 50\% (Semarbut asphalt type III).

The optimum bitumen content was obtained at mixing time 8 minutes 54 seconds. Based on research, can be obtained characteristics of emulsion asbuton extracted were penetration value of $5 \mathrm{dmm}$, softening point $92{ }^{\circ} \mathrm{C}$, flash point $252^{\circ} \mathrm{C}$, fuel point $259^{\circ} \mathrm{C}$, ductility $0 \mathrm{~cm}$, specific gravity $1.44 \mathrm{gr} / \mathrm{cc}$, stickiness to aggregate 100\% With the characteristic results of this asbuton extract can not be used as a binder on the surface layer, but can still be developed into additional material on asphalt penetration 60/70 as asphalt Semarbut Asphalt Type III content of 30\% asbuton emulsion extract meets asphalt modified asphalt requirements. Characteristics of Semarbut Asphalt Type III are penetration asphalt 56,9 dmm; softening point of $57^{\circ} \mathrm{C}$; flash point $290{ }^{\circ} \mathrm{C}$; burn point $310^{\circ} \mathrm{C}$; Ductility $55.5 \mathrm{~cm}$, specific gravity $1.15 \mathrm{~g} / \mathrm{cc}$, stickiness to aggregate $100 \%$.
\end{abstract}

Keywords: Emulsion Asbuton, Extraction, Mixing Time, Semarbut Asphalt Type III.

\begin{abstract}
ABSTRAK
Asbuton belum dapat dimanfaatkan secara optimal di Indonesia karena pemanfaatannya terbatas dalam bentuk butiran. Tujuan penelitian ini adalah menganalisis hubungan waktu mixing campuran bahan padat terhadap kadar aspal asbuton emulsi, karakteristik ekstrak asbuton emulsi, karakteristik Semarbut Aspal Tipe III dan penambahan ekstrak asbuton emulsi optimum yang memenuhi persyaratan aspal yang dimodifikasi dengan asbuton.

Asbuton emulsi terdiri dari bahan padat (asbuton butir 5/20 dan oli bekas yang dimixing dengan variasi waktu 3,5,7,9 dan 11 menit dengan waktu pemeraman 24 jam) dan bahan cair (texapon, HCl dan aquades). Ekstrak asbuton emulsi diuji nilai kadar aspal hingga diperoleh kadar aspal optimum kemudian mencampurkannya ke aspal penetrasi 60/70 dengan variasi kadar 30\%,35\%,40\%,45\% dan 50\% (Semarbut Aspal Tipe III).

Kadar aspal optimum diperoleh pada waktu mixing 8 menit 54 detik. Hasil pengujian karakteristik ekstrak asbuton emulsi adalah nilai penetrasi $5 \mathrm{dmm}$; titik lembek $92^{\circ} \mathrm{C}$; titik nyala $252^{\circ} \mathrm{C}$; titik bakar $259^{\circ} \mathrm{C}$; Daktilitas $0 \mathrm{~cm}$; berat jenis 1,44 gr/cc; kelekatan terhadap agregat 100\%. Dengan hasil karakteristik ekstrak asbuton tersebut belum dapat digunakan sebagai bahan pengikat pada lapis permukaan, namun masih bisa dikembangkan menjadi bahan tambah pada aspal penetrasi 60/70 sebagai modifikasi aspal Semarbut Aspal Tipe III. Semarbut Aspal Tipe III kadar ekstrak asbuton emulsi 30\% memenuhi persyaratan aspal yang dimodifikasi dengan asbuton. Karakteristik aspal Semarbut Aspal Tipe III adalah nilai penetrasi 56,9 dmm; titik lembek $57^{\circ} \mathrm{C}$; titik nyala $290^{\circ} \mathrm{C}$; titik bakar $310^{\circ} \mathrm{C}$; Daktilitas $55,5 \mathrm{~cm}$; berat jenis $1,15 \mathrm{gr} / \mathrm{cc}$; kelekatan terhadap agregat $100 \%$.
\end{abstract}

Kata Kunci: Asbuton Emulsi, Ekstraksi, Waktu Mixing, Semarbut Aspal Tipe III.

PENDAHULUAN

Asbuton (Aspal Buton) merupakan aspal alam yang masih tercampur dengan batuan dan terdapat di pulau Buton, Provinsi Sulawesi Tenggara. Indonesia memiliki cadangan aspal alam yang cukup besar sebagai substansi 
aspal minyak untuk memenuhi kekurangan kebutuhan aspal nasional namun pada pemanfaatannya belum optimal. Pemanfaatan asbuton masih terbatas dalam bentuk butiran atau biasa disebut asbuton butir.

Program pembangunan jalan di Indonesia yang telah dirancang oleh pemerintah mendorong adanya pemanfaatan asbuton agar penggunaan asbuton efektif dan efisien (Affandi, 2008), sehingga perlu dilakukan penelitian dan pengembangan produk asbuton maupun produk campuran beraspal. Salah satu metode pengolahan asbuton yang berkembang saat ini adalah ekstraksi asbuton. Ekstraksi asbuton merupakan metode pemisahan aspal murni dengan mineral-mineralnya. Tujuan dari ekstraksi asbuton adalah untuk mendapatkan aspal murni yang selanjutnya dapat digunakan seperti halnya aspal minyak. Namun aspal murni yang didapatkan dari hasil ekstraski asbuton apabila berdiri sendiri sebagai bahan pengikat pada perkerasan jalan raya belum bisa memberikan hasil yang maksimal sehingga perlu adanya modifikasi aspal dengan menggunakan aspal penetrasi 60/70.

Berdasarkan keempat penelitian tersebut maka peneliti melakukan penelitian lanjutan tentang ekstraksi asbuton emulsi dengan bahan peremaja oli bekas dan Semarbut Aspal Tipe III. Semarbut Aspal Tipe III adalah modifikasi hasil ekstraksi asbuton emulsi dengan aspal minyak penetrasi 60/70. Perbedaan antara Semarbut Aspal Tipe I, II, dan III adalah terletak pada bahan peremaja yang digunakan pada saat ekstraksi asbuton emulsi. Penelitian Semarbut Aspal Tipe I dan II masing-masing menggunakan bahan peremaja kerosin dan premium, sedangkan pada penelitian Semarbut Aspal Tipe III menggunakan bahan peremaja oli bekas.

Pada penelitian ini penulis mencoba untuk meningkatkan kadar optimum ekstraksi asbuton emulsi yang ditambahkan pada aspal penetrasi 60/70 sebagai aspal modifikasi.

\section{METODE}

Asbuton emulsi terdiri dari 2 campuran yaitu campuran bahan padat dan campuran bahan cair. Campuran bahan padat terdiri dari asbuton butir 5/20 dan oli bekas (hasil uji saybolt sebesar 59 detik) sedangkan campuran bahan cair terdiri dari $\mathrm{HCl}$, texapon dan aquades. Kadar campuran bahan padat diperoleh melalui proses trial and error di Laboratorium Jalan Raya UNS sedangkan data kadar campuran bahan cair menggunakan data penelitian sebelumnya yang dilakukan oleh Ponco Setiawan R (2016).

Pelaksanaan pembuatan asbuton dengan metode ekstraksi asbuton emulsi antara lain :

1) Pembuatan campuran bahan padat asbuton emulsi yang merupakan campuran asbuton butir $5 / 20$ dan bahan peremaja oli bekas. Asbuton butir dan oli bekas dicampur secara manual didalam wadah porselin kemudian ditutup menggunakan plastik sehingga kedap udara dan diperam selama 24 jam.

2) Mixing campuran asbuton butir $5 / 20$ dengan bahan peremaja oli bekas yang sudah diperam selama 24 jam menggunakan mixer modifikasi kecepatan $800 \mathrm{rpm}$ dengan variasi waktu yang sudah direncanakan yaitu 3, 5, 7, 9, 11 menit.

3) Pembuatan campuran bahan cair asbuton emulsi yang terdiri dari texapon, $\mathrm{HCl}$ dan aquades menggunakan mixer dengan kecepatan berkisar $100 \mathrm{rpm}$.

4) Mencampurkan campuran bahan padat dan campuran bahan cair menggunakan mixer modifikasi kecepatan $800 \mathrm{rpm}$.

5) Memodifikasi alat pada proses ekstraksi dengan menambahkan galvalum untuk menampung hasil ekstraksi halus, plat galvalum berlubang sebagai pengapit saringan no.40 diantara bowl dan penutup serta modifikasi penutup alat ekstraksi.

6) Memasukkan asbuton emulsi ke dalam bowl mesin ekstraksi. Mengekstraksi asbuton emulsi dengan kecepatan 2000 rpm selama $2 \times 25$ menit.

Hasil ekstraksi asbuton emulsi terdiri dari hasil halus dan hasil kasar. Hasil halus ekstrak asbuton emulsi diuji kadar aspal dengan metode kelarutan dalan TCE hingga diperoleh kadar aspal optimum. Waktu mixing yang menghasilkan kadar aspal optimum akan digunakan sebagai waktu mixing pembuatan produk asbuton untuk campuran aspal penetrasi 60/70 pada pembuatan Semarbut Aspal Tipe III.

Tabel 1. Variasi Campuran Ekstrak Asbuton Emulsi dan Aspal Penetrasi 60/70 (Semarbut Aspal Tipe III)

\begin{tabular}{ccc}
\hline \multirow{2}{*}{ Kode } & \multicolumn{2}{c}{ Komposisi } \\
\cline { 2 - 3 } & Ekstrak Asbuton Emulsi & Aspal Penetrasi 60/70 \\
\cline { 2 - 3 } & $(\%)$ & $(\%)$ \\
\hline K -30 & 30 & 70 \\
\hline K -35 & 35 & 65 \\
\hline$K-40$ & 40 & 60 \\
\hline$K-45$ & 45 & 55 \\
\hline$K-50$ & 50 & 50 \\
\hline
\end{tabular}


Semarbut Aspal Tipe III merupakan campuran dari ekstrak asbuton emulsi dan aspal penetrasi 60/70. Semarbut Aspal Tipe III diuji nilai karakteristik aspal yang meliputi uji penetrasi, daktilitas, titik lembek, titik nyala dan titik bakar, berat jenis dan kelekatan. Metode pencampuran yang digunakan adalah panas-panas yaitu memanaskan aspal penetrasi $60 / 70$ hingga suhu $150^{\circ} \mathrm{C}$ dan mencampurkan ke campuran panas ekstrak asbuton emulsi yang memiliki suhu $150^{\circ} \mathrm{C}$ dengan menggunakan mixer.

\section{HASIL DAN PEMBAHASAN}

\section{Hasil Pengujian Kadar Aspal Ekstrak Asbuton Emulsi Dengan Metode Kelarutan Dalam TCE}

Uji kelarutan aspal dalam Tricbloroetbylene (TCE) mengacu pada SNI 2438-2015 yaitu tentang cara uji kelarutan aspal. Uji kelarutan aspal digunakan untuk mengetahui persentase kadar aspal yang terkandung dalam ekstrak asbuton emulsi. Hasil uji kadar aspal ekstrak asbuton emulsi ditunjukkan pada Tabel 2.

Tabel 2. Hasil Uji Kadar Aspal Ekstrak Asbuton Emulsi

\begin{tabular}{cccccc}
\hline \multirow{2}{*}{ Benda Uji } & \multicolumn{5}{c}{ Kadar Aspal Pada Variasi Waktu Mixing Campuran Bahan Padat } \\
\cline { 2 - 6 } & $\mathbf{3}$ menit & $\mathbf{5}$ menit & $\mathbf{7 ~ m e n i t}$ & $\mathbf{9}$ menit & $\mathbf{1 1}$ menit \\
\cline { 2 - 6 } & $\mathbf{( \% )}$ & $\mathbf{( \% )}$ & $\mathbf{( \% )}$ & $\mathbf{( \% )}$ & $\mathbf{( \% )}$ \\
\hline 1 & 78.50 & 79.50 & 83.50 & 85.00 & 81.00 \\
\hline 2 & 79.50 & 81.50 & 82.50 & 84.00 & 83.50 \\
\hline 3 & 79.50 & 81.00 & 84.00 & 84.00 & 83.50 \\
\hline Rata-rata & $\mathbf{7 9 . 1 7}$ & $\mathbf{8 0 . 6 7}$ & $\mathbf{8 3 . 3 3}$ & $\mathbf{8 4 . 3 3}$ & $\mathbf{8 2 . 6 7}$ \\
\hline
\end{tabular}

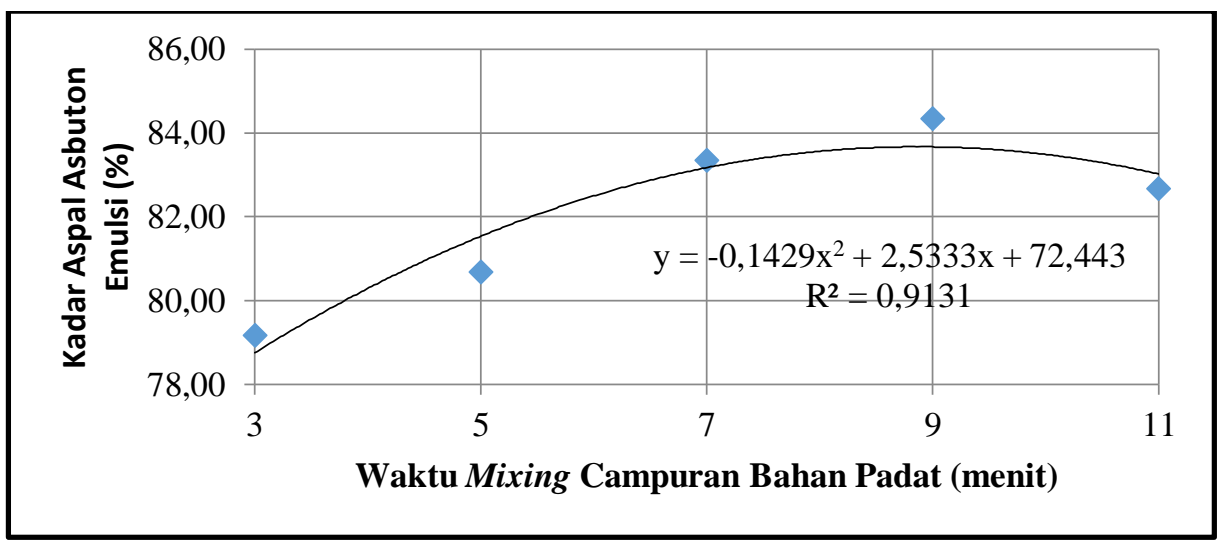

Gambar 1 Grafik Hubungan Waktu Mixing Campuran Bahan Padat dengan Kadar Aspal Asbuton Emulsi

Gambar 1 menunjukkan bahwa semakin lama waktu mixing campuran bahan padat maka akan diperoleh kadar aspal dalam asbuton emulsi hasil ekstraksi yang semakin tinggi hingga pada waktu tertentu mengalami penurunan. Semakin lama waktu mixing campuran bahan padat maka bahan peremaja (oli bekas) akan semakin banyak mengikat aspal yang terkandung dalam asbuton butir. Namun, apabila waktu mixing campuran bahan padat ditambah secara terus-menerus maka mineral asbuton butir akan semakin halus dan terikat oleh bahan peremaja sehingga ekstrak halus yang dihasilkan akan mengandung banyak filler dan filler tersebut akan lolos saringan. Waktu mixing dengan nilai kadar aspal optimum yang diperoleh berdasarkan persamaan $-0.1429 \mathrm{x}^{2}+$ $2.5333 x+72.443$ adalah 8 menit 52 detik. Nilai koefisien korelasi $r=0.96$ menunjukkan hubungan yang sangat kuat antara waktu mixing pada campuran bahan padat dengan kadar aspal asbuton emulsi. Asbuton emulsi dengan waktu mixing campuran bahan padat 8 menit 52 detik diperoleh kadar aspal optimum, sehingga campuran inilah yang akan diuji karakteristik aspalnya.

\section{Hasil Pengujian Karakteristik Hasil Ekstraksi Asbuton Emulsi}

Tabel 3. Rekapitulasi Hasil Pengujian Karakteristik Aspal Ekstraksi Asbuton Emulsi

\begin{tabular}{clccc}
\hline No & Nama Pengujian & Pedoman Pengujian & Nilai uji & Satuan \\
\hline $\mathbf{1}$ & Daktilitas & SNI 06-2432-1991 & 0 & $\mathrm{~cm}$ \\
\hline $\mathbf{2}$ & Penetrasi & RSNI 06-2456-1991 & 5 & $\mathrm{dmm}$ \\
\hline
\end{tabular}




\begin{tabular}{cllcc}
\hline $\mathbf{3}$ & Titik Lembek & RSNI 06-2434-1991 & 92 & ${ }^{\circ} \mathrm{C}$ \\
\hline $\mathbf{4}$ & Titik Nyala dan Bakar & SNI 06-2433-1991 & 252 dan 259 & ${ }^{\circ} \mathrm{C}$ \\
\hline $\mathbf{5}$ & Berat Jenis & SNI 06-2441-1991 & 1,44 & $\mathrm{gr} / \mathrm{cc}$ \\
\hline $\mathbf{6}$ & Kelekatan & PA-0312-76 & 100 & $\%$ \\
\hline
\end{tabular}

Hasil produk aspal hasil ekstraksi asbuton emulsi yang ditunjukkan pada Tabel 3 belum dapat digunakan sebagai bahan pengikat dalam lapis perkerasan karena memiliki nilai daktilitas $0 \mathrm{~cm}$ (belum terukur). Namun hasil produk ini bisa dikembangkan lagi menjadi bahan tambah pada aspal penetrasi 60/70 guna mengurangi jumlah pemakaian aspal penetrasi 60/70 serta mengoptimalkan penggunaan aspal asbuton.

\section{Hasil Pengujian Karakteristik Variasi Semarbut Aspal Tipe III}

\section{Hasil Uji Penetrasi}

Hasil uji penetrasi variasi Semarbut Aspal Tipe III ditunjukkan pada Gambar 2.

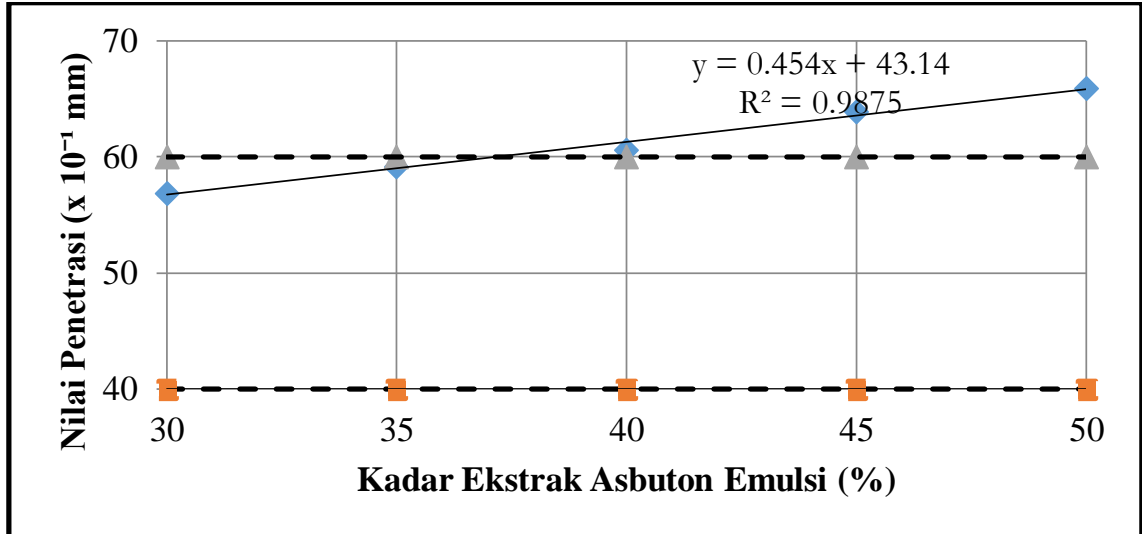

Persyaratan Nilai Penetrasi Aspal yang Dimodifikasi dengan Asbuton $=40-60 \times 10^{-1} \mathrm{~mm}$ Sumber : Pedoman Konstruksi dan Bangunan, No:001-01/BM/2006.

Gambar 2 Grafik Hasil Uji Penetrasi Variasi Semarbut Aspal Tipe III

Gambar 2 menunjukkan bahwa penambahan ekstrak asbuton emulsi pada aspal penetrasi 60/70 membuat nilai penetrasi semakin naik. Nilai koefisien korelasi $\mathrm{r}=0.99$ menunjukkan hubungan yang sangat kuat antara kadar ekstrak asbuton emulsi dengan nilai penetrasi campuran aspal penetrasi $60 / 70$ dengan aspal hasil ekstraksi asbuton emulsi dengan bahan peremaja oli bekas.

Nilai penetrasi penambahan kadar ekstraksi asbuton emulsi sebesar 30\% dan 35\% diantara 40 - 60 dmm sehingga memenuhi persyaratan aspal yang dimodifikasi dengan asbuton, sedangkan untuk penambahan kadar ekstrak asbuton emulsi sebesar 40\%, 45\% dan 50\% tidak memenuhi persyaratan tersebut karena memiliki nilai penetrasi lebih dari $60 \mathrm{dmm}$.

\section{Hasil Uji Titik Lembek}

Hasil uji titik lembek variasi Semarbut Aspal Tipe III ditunjukkan pada Gambar 3.

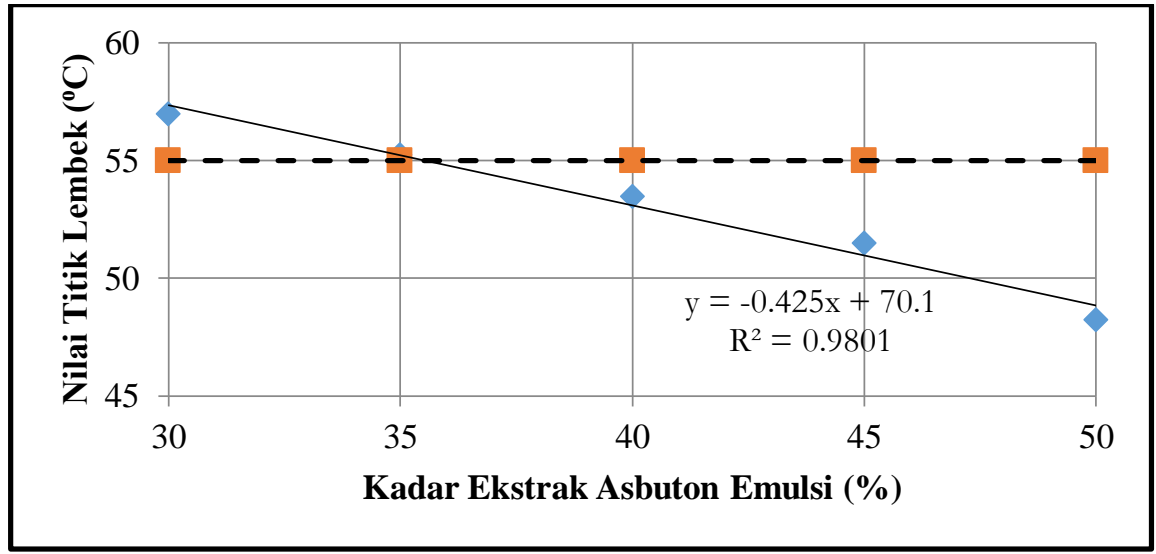

Persyaratan Nilai Titik Lembek Aspal yang Dimodifikasi dengan Asbuton $=\min 55^{\circ} \mathrm{C}$ 
Sumber : Pedoman Konstruksi dan Bangunan, No:001-01/BM/2006.

Gambar 3 Grafik Hasil Uji Titik Lembek Variasi Semarbut Aspal Tipe III

Gambar 3 menunjukkan bahwa penambahan ekstrak asbuton emulsi pada aspal penetrasi 60/70 membuat nilai titik lembek semakin turun. Penambahan ekstrak asbuton emulsi membuat nilai titik lembek semakin rendah, hal ini dikarenakan bahan peremaja yang digunakan adalah oli bekas. Oli bekas dan aspal penetrasi merupakan produk penyulingan yang sama-sama memiliki ikatan non polar. Oli bekas yang dicampur dengan aspal penetrasi memiliki sifat melarutkan sehingga nilai titik lembek semakin menurun seiring penambahan kadar asbuton emulsi pada Semarbut Aspal Tipe III. Nilai koefisien korelasi $r=0.99$ menunjukkan hubungan yang sangat kuat antara kadar ekstrak asbuton emulsi dengan nilai titik lembek campuran aspal penetrasi 60/70 dengan aspal hasil ekstraksi asbuton emulsi dengan bahan peremaja oli bekas.

Nilai titik lembek penambahan kadar ekstraksi asbuton emulsi sebesar $30 \%$ dan $35 \%$ lebih dari $55^{\circ} \mathrm{C}$ sehingga memenuhi persyaratan aspal yang dimodifikasi dengan asbuton, sedangkan untuk penambahan kadar ekstrak asbuton emulsi sebesar 40\%, 45\% dan 50\% tidak memenuhi persyaratan tersebut karena memiliki nilai titik lembek kurang dari $55^{\circ} \mathrm{C}$.

\section{Hasil Uji Titik Nyala dan Titik Bakar}

Hasil uji titik nyala dan titik bakar variasi Semarbut Aspal Tipe III ditunjukkan pada Gambar 4.

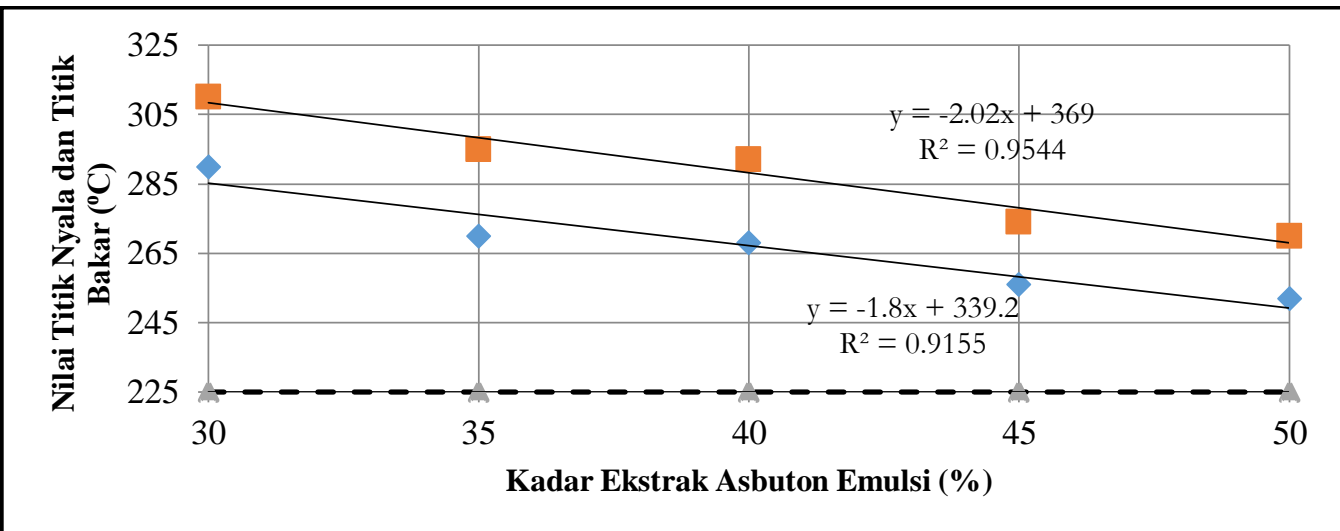

Persyaratan Nilai Titik Nyala Aspal yang Dimodifikasi dengan Asbuton $=\min 225^{\circ} \mathrm{C}$

Sumber : Pedoman Konstruksi dan Bangunan, No:001-01/BM/2006.

Gambar 4 Grafik Hasil Uji Titik Nyala dan Titik Bakar Variasi Semarbut Aspal Tipe III

Gambar 4 menunjukkan bahwa penambahan ekstrak asbuton emulsi pada aspal penetrasi 60/70 membuat nilai titik nyala dan titik bakar semakin turun. Penurunan suhu pada titik nyala dan titik bakar dikarenakan masih adanya kandungan oli bekas dalam ekstrak asbuton. Nilai koefisien korelasi $r=0.95$ dan $r=98$ menunjukkan hubungan yang sangat kuat antara kadar ekstrak asbuton emulsi dengan nilai titik nyala dan titik bakar campuran aspal penetrasi 60/70 dengan aspal hasil ekstraksi asbuton emulsi dengan bahan peremaja oli bekas

Nilai titik nyala dan titik bakar penambahan kadar ekstraksi asbuton emulsi sebesar 30\%, 35\%, 40\%, 45\% dan $50 \%$ memenuhi persyaratan aspal yang dimodifikasi dengan asbuton dengan suhu titik nyala minimal $225^{\circ} \mathrm{C}$.

\section{Hasil Uji Daktilitas}

Hasil uji daktilitas variasi Semarbut Aspal Tipe III ditunjukkan pada Gambar 5. 


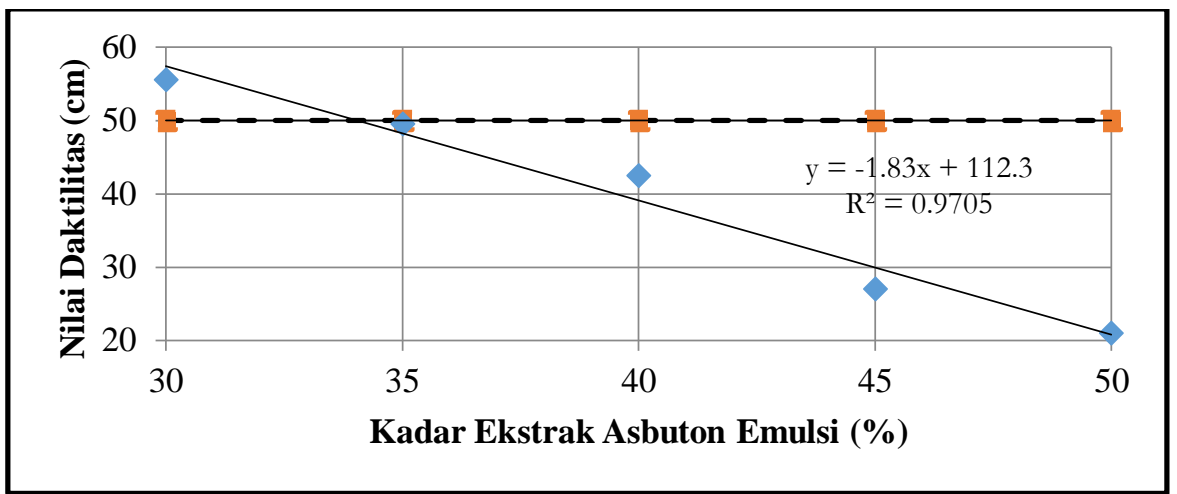

Persyaratan Nilai Daktilitas Aspal yang Dimodifikasi dengan Asbuton $=\min 50 \mathrm{~cm}$

Sumber : Pedoman Konstruksi dan Bangunan, No:001-01/BM/2006.

Gambar 5 Grafik Hasil Uji Daktilitas Variasi Semarbut Aspal Tipe III

Gambar 5 menunjukkan bahwa penambahan ekstrak asbuton emulsi pada aspal penetrasi 60/70 membuat nilai daktilitas semakin turun. Nilai koefisien korelasi $r=0.99$ menunjukkan hubungan yang sangat kuat antara kadar ekstrak asbuton emulsi dengan nilai daktilitas campuran aspal penetrasi 60/70 dengan aspal hasil ekstraksi asbuton emulsi dengan bahan peremaja oli bekas.

Nilai daktilitas penambahan kadar ekstraksi asbuton emulsi sebesar 30\% lebih dari $50 \mathrm{~cm}$ sehingga memenuhi persyaratan aspal yang dimodifikasi dengan asbuton, sedangkan untuk penambahan kadar ekstrak asbuton emulsi sebesar 35\%, 40\%, 45\% dan 50\% tidak memenuhi persyaratan tersebut karena memiliki nilai daktilitas kurang dari $50 \mathrm{~cm}$.

\section{Hasil Uji Berat Jenis}

Hasil uji berat jenis variasi Semarbut Aspal Tipe III ditunjukkan pada Gambar 6.

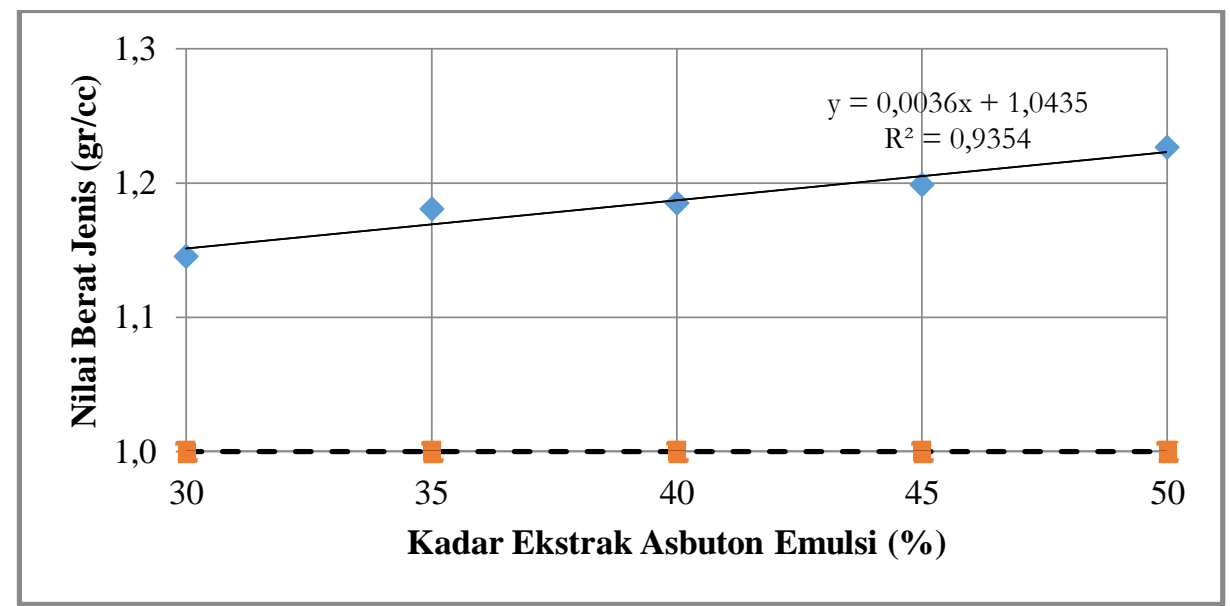

Persyaratan Nilai Berat Jenis Aspal yang Dimodifikasi dengan Asbuton $=$ min $1 \mathrm{gr} / \mathrm{cc}$ Sumber : Pedoman Konstruksi dan Bangunan, No:001-01/BM/2006

Gambar 6 Grafik Hasil Uji Berat Jenis Variasi Semarbut Aspal Tipe III

Gambar 6 menunjukkan bahwa penambahan ekstrak asbuton emulsi pada aspal penetrasi 60/70 membuat nilai berat jenis semakin naik. Nilai koefisien korelasi $r=0.98$ menunjukkan hubungan yang sangat kuat antara kadar ekstrak asbuton emulsi dengan nilai berat jenis campuran aspal penetrasi 60/70 dengan aspal hasil ekstraksi asbuton emulsi dengan bahan peremaja oli bekas.

Nilai berat jenis penambahan kadar ekstraksi asbuton emulsi sebesar 30\%, 35\%, 40\%, 45\% dan 50\% memenuhi persyaratan aspal yang dimodifikasi dengan asbuton dengan nilai berat jenis minimal $1 \mathrm{gr} / \mathrm{cc}$.

\section{Hasil Uji Kelekatan}

Hasil uji kelekatan variasi Semarbut Aspal Tipe III ditunjukkan pada Tabel 4.

Tabel 4. Rekapitulasi Hasil Uji Kelekatan Variasi Semarbut Tipe III.

No Kode Kelekatan $(\%)$




\begin{tabular}{lll}
\hline $\mathbf{1}$ & $\mathrm{K}-30$ & 100 \\
\hline $\mathbf{2}$ & $\mathrm{K}-35$ & 100 \\
\hline $\mathbf{3}$ & $\mathrm{K}-40$ & 100 \\
\hline $\mathbf{4}$ & $\mathrm{K}-45$ & 100 \\
\hline $\mathbf{5}$ & $\mathrm{K}-50$ & 100 \\
\hline
\end{tabular}

Nilai uji kelekatan pada semua variasi memenhi persyaratan aspal yang dimodifikasi dengan asbuton. Nilai kelekatan 100\% menunjukkan bahwa modifikasi aspal dengan penambahan ekstrak asbuton pada aspal penetrasi 60/70 (Semarbut Aspla Tipe III) memiliki sifat adhesi aspal yang baik.

\section{Hasil Uji Kadar Kelarutan Aspal Variasi Komposisi Semarbut Aspal Tipe III}

Hasil uji kelekatan variasi Semarbut Aspal Tipe III ditunjukkan pada Gambar 6.

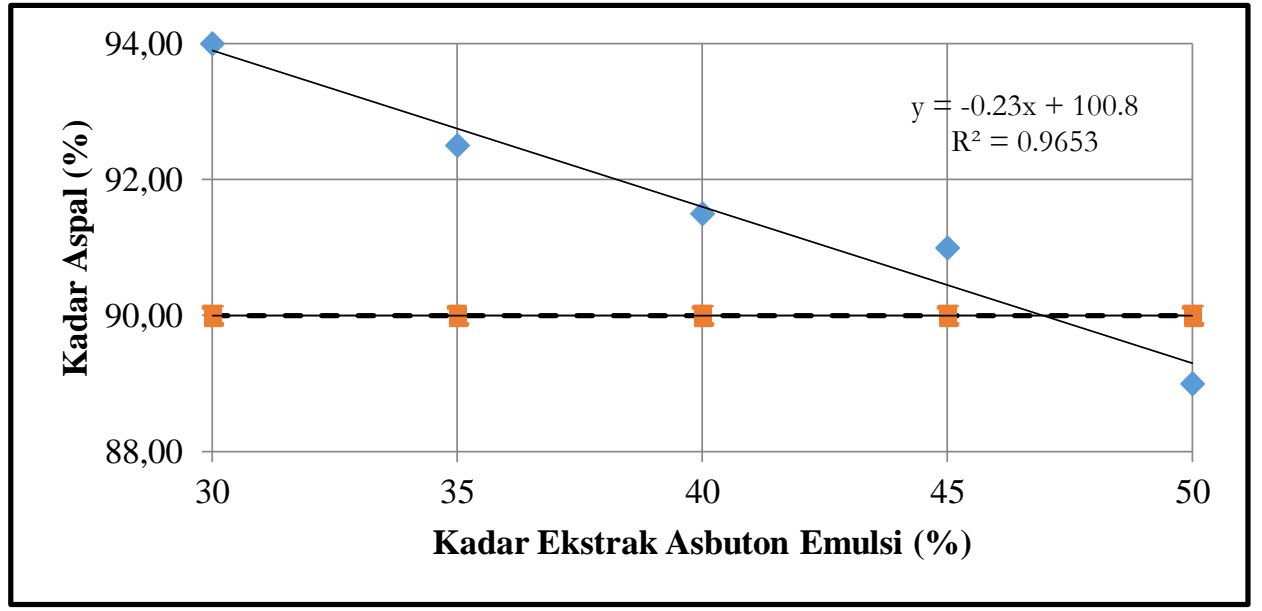

Gambar 7 Grafik Hasil Uji Kelarutan Variasi Semarbut Aspal Tipe III

Gambar 7 menunjukkan bahwa penambahan ekstrak asbuton emulsi pada aspal penetrasi 60/70 membuat nilai kelarutan semakin turun. Nilai koefisien korelasi $\mathrm{r}=0.98$ menunjukkan hubungan yang sangat kuat antara kadar ekstrak asbuton emulsi dengan nilai kelarutan campuran aspal penetrasi 60/70 dengan aspal hasil ekstraksi asbuton emulsi dengan bahan peremaja oli bekas.

Nilai kelarutan penambahan kadar ekstraksi asbuton emulsi sebesar 30\%, 35\%, 40\% dan 45\% memenuhi persyaratan aspal yang dimodifikasi dengan asbuton dengan nilai kelarutan minimal 90\%. Sedangkan penambahan kadar ekstraksi asbuton emulsi sebesar 50\% tidak memenuhi persyaratan tersebut karena memiliki nilai kelarutan kurang dari $90 \%$.

\section{Indeks Penetrasi Variasi Komposisi Semarbut Aspal Tipe III}

Tabel 5. Hasil Analisis Perhitungan Indeks Penetrasi

\begin{tabular}{cccccc}
\hline No & Kode & $\begin{array}{c}\text { Nilai } \\
\text { Penetrasi } \\
(\mathbf{x 1 0 - 1} \mathbf{~ m m})\end{array}$ & $\begin{array}{c}\text { Titik } \\
\text { Lembek } \\
\left({ }^{\mathbf{0}} \mathbf{C}\right)\end{array}$ & A & $\begin{array}{c}\text { Indeks } \\
\text { Penetrasi }\end{array}$ \\
\hline $\mathbf{1}$ & K - 30 & 56.9 & 57.00 & 0.0359 & 0.74 \\
\hline $\mathbf{2}$ & K - 35 & 59.2 & 55.25 & 0.0374 & 0.46 \\
\hline $\mathbf{3}$ & K - 40 & 60.6 & 53.50 & 0.0393 & 0.11 \\
\hline $\mathbf{4}$ & K - 45 & 63.9 & 51.50 & 0.0414 & -0.23 \\
\hline $\mathbf{5}$ & K - 50 & 65.9 & 48.25 & 0.0466 & -0.99 \\
\hline
\end{tabular}




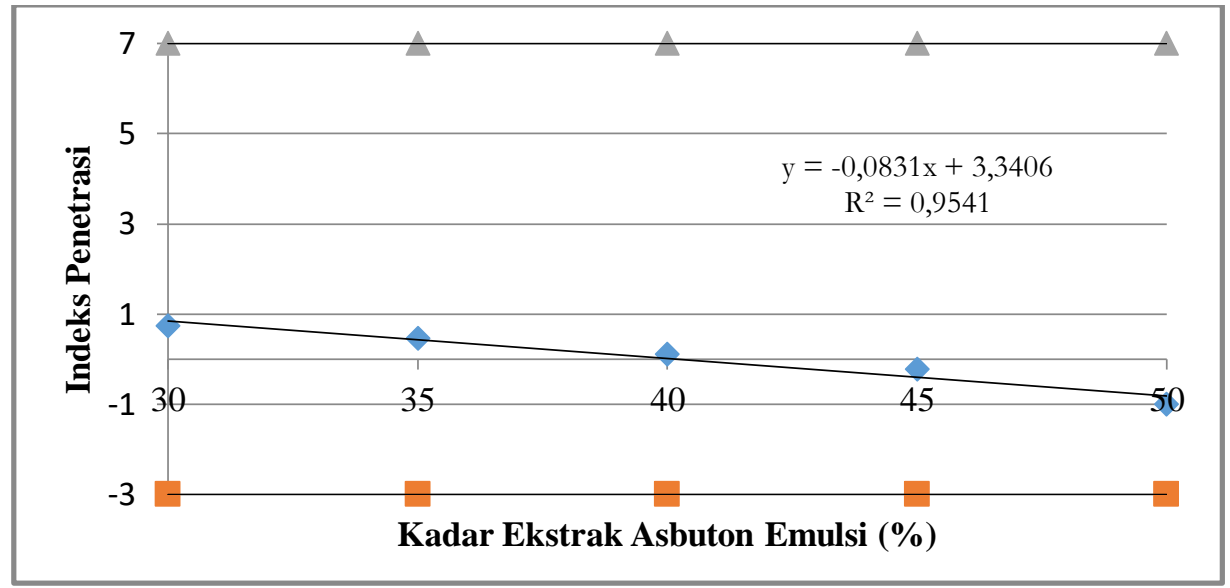

Persyaratan Indeks Penetrasi -3 hingga +7, Sumber : The Shell Aspal Handbook

Gambar 8 Grafik Hasil Indeks Penetrasi Variasi Semarbut Aspal Tipe III

Gambar 8 menunjukkan bahwa penambahan ekstrak asbuton emulsi pada aspal penetrasi 60/70 membuat nilai indeks penetrasi semakin turun. Nilai Indeks penetrasi pada semua variasi memenuhi persyaratan antara -3 hingga +7 .

\section{SIMPULAN}

Simpulan yang diperoleh dari penelitian ini adalah sebagai berikut :

1. Waktu mixing pada campuran bahan padat ekstraksi asbuton emulsi dengan waktu mixing 8 menit 54 detik menghasilkan kadar aspal optimum yaitu sebesar $83.67 \%$.

2. Hasil pengujian karakteristik aspal dari ekstrak asbuton emulsi dengan kadar kelarutan optimum adalah sebagai berikut :

- nilai penetrasi $: 5 \mathrm{dmm}$;

- titik lembek $\quad: 92^{\circ} \mathrm{C}$;

- titik nyala $\quad: 252^{\circ} \mathrm{C}$;

- titik bakar $\quad: 259^{\circ} \mathrm{C}$;

- Daktilitas : $0 \mathrm{~cm}$;

- berat jenis : $1,44 \mathrm{gr} / \mathrm{cc}$;

- kelekatan terhadap agregat : $100 \%$.

3. Komposisi Semarbut Aspal Tipe III yang memnuhi persyaratan aspal yang dimodifikasi dengan asbuton adalah ekstrak asbuton emulsi dengan kadar 30\% dan aspal penetrasi 60/70 dengan kadar sebesar 70\%.

4. Hasil pengujian karakteristik aspal dari Semarbut Aspal Tipe III adalah sebagai berikut :

- nilai penetrasi : 56,9 dmm;

- titik lembek $\quad: 57^{\circ} \mathrm{C}$;

- titik nyala $\quad: 290^{\circ} \mathrm{C}$;

- titik bakar $\quad: 310^{\circ} \mathrm{C}$;

- Daktilitas : $55,5 \mathrm{~cm}$;

- berat jenis : $1,1455 \mathrm{gr} / \mathrm{cc}$;

- kelekatan terhadap agregat : $100 \%$.

\section{DAFTAR PUSTAKA}

Cahya, Didit. 2015. Ekstraksi Asbuton dengan Menggunakan Metode Asbuton Emulsi Menggunakan Emulgator Texapon Ditinjau dari Konsentrasi HCl dan Waktu Ekstraksi. Surakarta: Universitas Sebelas Maret

Januar E, sadu 2014. Kinerja Properti Semarbut Aspal Tipe I (Penambahan Ekstraksi Asbuton Emulsi Sebagai Modifikasi Bitumen). Surakarta: Universitas Sebelas Maret

Kementrian Pekerjaan Umum. 1991. SNI 06-2432 tentang pengujian daktilitas aspal. Jakarta.

Kementrian Pekerjaan Umum. 1991. SNI 06-2433 tentang pengujian titik nyala, titik bakar aspal. Jakarta.

Kementrian Pekerjaan Umum. 1991. SNI 06-2434 tentang pengujian titik lembek aspal. Jakarta.

Kementrian Pekerjaan Umum. 1991. SNI 06-2439 tentang pengujian kelekatan bitumen terhadap agregat. Jakarta.

Kementrian Pekerjaan Umum. 1991. SNI 06-2441 tentang aspal padat, Metode pengujian berat jenis. Jakarta. 
Kementrian Pekerjaan Umum. 1991. SNI 06-2456 tentang pengujian penetrasi aspal. Jakarta.

Kementrian Pekerjaan Umum. 1991. SNI 06-2488 tentang pengujian berat jenis aspal. Jakarta.

Kementrian Pekerjaan Umum Ditjen Bina Marga. 2006. Pemanfaatan Asbuton. Pedoman No: 001-01/BM/ 2006.

Setiawan R, Ponco., 2016. Ekstraksi Asbuton Butir Menggunakan Metode Asbuton Emulsi Ditinjau dari Waktu Mixing Fase Padat dengan Emulgator Texapon dan Grinder Tipe MB 60. Surakarta: Universitas Sebelas Maret.

Surya D, Rifqi. 2016. Pengaruh Waktu Pemeraman Fase Padat pada Asbuton Emulsi Terhadap Kadar Aspal Dengan Emulgator Texapon Menggunakan Girder Tipe MB 60. Surakarta: Universitas Sebelas Maret.

Try W, Luqman. 2016. Karakteristik Penambahan Ekstraksi Asbuton Emulsi pada Aspal Penetrasi 60/70 Sebagai Modifikasi Bitumen (Semarbut Aspal Tipe II). Surakarta: Universitas Sebelas Maret

Widhisasongko, Arif. 2015. Ekstraksi Asbuton dengan Metode Asbuton Emulsi Menggunakan Emulgator Texapon Ditinjau dari Konsentrasi Kerosin dan Waktu Mixing Fase Padat. Surakarta: Universitas Sebelas Maret. 